\begin{tabular}{|l|l|l|l|l|l|}
\hline J. Tek. Ling & Vol.11 & No.1 & Hal. 95 - 103 & Jakarta, Januari 2010 & ISSN 1441-318X \\
\hline
\end{tabular}

\title{
PELUANG PENERAPAN PRODUKSI BERSIH PADA KAWASAN INDUSTRI PERIKANAN MUNCAR KABUPATEN BANYUWANGI JAWA TIMUR
}

\author{
Lestario Widodo \\ Peneliti di Pusat Teknologi Lingkungan \\ Badan Pengkajian dan Penerapan Teknologi
}

\begin{abstract}
Coastal areas in Muncar Banyuwangi has developed one of the largest fisherys industry centers in Indonesia. Fisherys industry in the production process using a fish as a main input and also need a lot of clean water. The impact of these activities is the occurrence of environmental pollution in the form of liquid waste and the unpleasant smell. Cleaner produktion is minimization of waste from source. The application of cleaner production with its assessment and identification to production process will create any innovations. In the cleaner production method contains several strategies that can be implemented for reducing and minimizing of industrial waste including prevention, recycling, treatment and disposing. One of prospective instruments that can be developed further in the industrial implementation of cleaner production is fisherys industry at Muncar Banyuwangi. The main opportunities to implementation of cleaner production, especially in stages using excessive water in the process of weeding and cleaning fish, stage of the main raw material the use of fish by re-sorting a more effective, and efficient charging process scattered on the tin.
\end{abstract}

Key words : Cleaner production, fisherys industry

\section{PENDAHULUAN}

Seperti diketahui pada awalnya strategi pengelolaan lingkungan didasarkan pada pendekatan kapasitas daya dukung (carrying capacity). Penerapan daya dukung lingkungan ini ternyata sulit karena banyak kendala yang timbul dan sering kali kondisi lingkungan terlanjur tercemar dan rusak, sehingga perlu biaya besar untuk memulihkannya. Pengelolaan lingkungan kemudian berkembang menjadi upaya untuk mengatasi masalah pencemaran dengan cara mengelola limbah yang terbentuk ${ }^{1}$ (endof pipe), dengan harapan kualitas lingkungan hidup dapat lebih ditingkatkan. Langkah yang ditempuh tersebut ternyata masih belum cukup, karena biaya teknologi pengolahan limbah yang besar, serta pentaatan aturan dan pendekatan hukum tidak efektif akibatnya pencemaran lingkungan tetap terjadi. Untuk itu diperlukan pendekatan yang lebih menyeluruh dengan berorientasi pada hemat biaya sehingga sekaligus berperan bagi peningkatan daya saing, pencegahan pencemaran yang mengurangi terbentuknya limbah dan memfasilitasi semua pihak untuk mengelola lingkungan secara hematbiaya serta memberi keuntungan baik finansial maupun non finansial. Pencegahan pencemaran lingkungan secara mendasar mengalihkan fokus pengelolaan lingkungan dari penanggulangan melalui end of pipe menjadi berkembangnya pemikiran frontof-process yang preventif dengan prinsip bahwa pencemaran seharusnya tidak boleh terjadi. Pendekatan pengelolaan lingkungan yang bersifat proaktif, preventif dan front of 
process kemudian dikenal dengan produksi bersih (Cleaner Production) $)^{2}$.

Limbah dan emisi pada hakekatnya merupakan hasil yang tidak diinginkan dari setiap kegiatan industri. Sebagian pelaku usaha masih berpandangan bahwa limbah bukanlah menjadi suatu permasalahan dan kalau perlu keberadaannya disembunyikan. Pihak industri mungkin masih belum menyadari bahwa sebenarnya limbah disini adalah sama dengan uang, artinya bahwa limbah merupakan uang atau biaya yang harus dikeluarkan dan mengurangi keuntungan ${ }^{3}$. Dengan demikian apabila limbah itu dapat dicegah menjadi seminimal mungkin maka akan menghasilkan penghematan biaya atau dengan kata lain keuntungannya dapat meningkat.

Wilayah pesisir di Kecamatan Muncar telah berkembang menjadi salah satu sentra industri perikanan terbesar di Indonesia. Industri perikanan dalam proses produksinya selain menggunakan ikan sebagai input utamanya juga memerlukan air bersih yang banyak. Dari proses tersebut berdampak pada masalah lingkungan berupa limbah cair, serta bau yang tidak sedap. Setelah sekian lama, penanganan masalah limbah industri perikanan tersebut oleh Pemerintah Kabupaten Banyuwangi belum banyak membuahkan hasil. Hal ini dikarenakan keberadaan limbah industri perikanan berdampak pada tumbuhnya sektor usaha non formal yang lepas dari rencana penataan kawasan yang telah berlangsung selama bertahun-tahun. Hal ini terjadi mengingat limbah yang dibuang oleh kegiatan industri perikanan mempunyai nilai ekonomis yang cukup tinggi. Daerah pesisir Muncar adalah daerah penghasil ikan terbesar di Indonesia yang terletak di dalam Kabupaten Banyuwangi dengan kegiatan utama penangkapan ikan dan industri perikanan. Industri perikanan yang ada di dalam klaster industri saat ini menimbulkan pencemaran lingkungan dan kualitas lingkungan yang tidak sehat dan dibawah standar. Pencemaran ini juga telah mempengaruhi kualitas perairan laut di wilayah perairan Muncar, sehingga mengakibatkan merosotnya sumberdaya perairan dan hasil tangkapan ikan nelayan. Hal ini terutama akibat pembuangan limbah industri yang tidak dikelola sesuai dengan baku mutu lingkungan dan peraturan yang berlaku ke dalam sungai dan saluran-saluran drainase. Salah satu upaya pengelolaan lingkungan di kawasan industri perikanan Muncar adalah dengan pendekatan produksi bersih. Melalui penerapan produksi bersih diharapkan limbah yang dihasilkan menjadi minimal, disisi lain pelaku industri perikanan dapat lebih menghemat biaya yang pada akhirnya apabila diemplementasikan pada seluruh industri di kawasan tersebut akan memberikan kontribusi yang signifikan bagi upaya pengelolaan kawasan industri.

\section{PRODUKSI BERSIH}

Pada tahun 1990 an UNEP ${ }^{4)}$ (United Nations Enviroment Program) memperkenalkan konsep produksi bersih yang didefenisikan sebagai : "Suatu strategi pengelolaan lingkungan yang bersifat preventif dan terpadu yang perlu diterapkan secara terus menerus pada proses produksi dan daur hidup produk dengan tujuan untuk mengurangi resiko terhadap manusia dan lingkungan." Produksi bersih adalah suatu program strategis yang bersifat proaktif yang diterapkan untuk menselaraskan kegiatan pembangunan ekonomi dengan upaya perlindungan lingkungan. Dasar Hukum Pelaksanaan Produksi Bersih adalah UU RI No. 32 Tabun 2009 Tentang Perlindungan dan Pengelolaan Lingkungan Hidup ${ }^{5}$.

Teknologi produksi bersih adalah sebuah upaya pendekatan minimalisasi limbah, yang merupakan strategi dalam meningkatkan efisiensi dan keuntungan untuk industri-industri atau para pelaku usaha pada saat yang bersamaan, dapat mengurangi beban lingkungan. Dengan menerapkan langkah-langkah produksi bersih, pelaku usaha diharapkan dapat meningkatkan keuntungan, meningkatkan kualitas pengelolaannya, meningkatkan 
kepedulian social masyarakat sekitar dan mengurangi buangan/emisinya pada lingkungan. Dengan demikian sangat penting untuk meningkatkan penerapan produksi bersih ini disemua sektor.

Teknologi produksi bersih didefinisikan sebagai strategi pengelolaan lingkungan yang bersifat prefentif, terpadu dan terus menerus pada setiap kegiatan mulai hulu ke hilir yang terkait dengan proses produksi, produk dan jasa untuk meningkatkan efisiensi penggunaan sumber daya alam, mencegah terjadinya pencemaran lingkungan mengurangi terbentuknya limbah pada sumbernya sehingga dapat meminimisasi resiko terhadap kesehatan dan keselamatan manusia serta kerusakan lingkungan. Kesadaran akan perlunya menangani problem limbah sejak dari huluya terus dikembangkan. Sejak tahun 1980-an kajian tentang teknologi yang ramah lingkungan menjadi prioritas. Prinsip utama konsep ini adalah mencegah terjadinya polusi dengan menggunakan proses produksi yang lebih bersih (cleaner production) atau mengintegrasikan prinsip ekologi dalam proses (eco-efficiency) ${ }^{6}$. Produksi bersih ini merupakan generasi kedua perkembangan teknologi lingkungan. Dalam produksi lebih bersih, langkah praktisnya adalah bagaimana suatu proses dapat :

a. Mengurangi pemakaian energi dan bahan mentah produksi.

b. Mengurangi limbah yang dihasilkan.

c. Memperbesar potensi pendaurulangan bahan mentah produksi dan produk samping (by-product) ${ }^{6}$.

Ada berbagai cara untuk menerapkan langkah-langkah meningkatkan efisiensi untuk proses, produk dan layanan. Caracara yang potensial untuk penerapan produksi bersih yaitu melalui metodologi untuk mencapai tujuan dalam produksi bersih yang dilengkapi dengan pedoman teknis. Pemilihan teknologi ini dan pedoman berdasarkan penggunaannya di Indonesia termasuk komprehensivitasnya serta kemudahan untuk dipraktekan.

Pendekatan yang digunakan dalam penerapan Teknologi Produksi Bersih yaitu dengan cara sebagai berikut :

1. Melakukan Tata kelola yang apik (Good House Keeping, GHK).

2. Pengelolaan Bahan Kimia (Chemical Management, CM)

Di dalam hal ini memfokuskan pada peningkatan produktivitas, penghematan biaya, pengurangan dampak lingkungan dan peningkatan prosedur organisasi serta keselamatan di tempat kerja. Metodologi yang lain secara lebih khusus memfokuskan pada penerapan fisik langkah-langkah Produksi Bersih yang merupakan gabungan antara dua konsep Produksi Bersih dan Efisiensi Energi.

Perspektif Ekonomi menjadi kunci utama atas penerapan Produksi Bersih, oleh karena itu dalam pengembilan keputusan upaya perbaikan dijelaskan pula metodologi ekonomi yaitu analisa biaya keuntungan (CBA, Cost Benefit Analysis) $)^{7)}$ untuk Produksi Bersih dan Akuntansi Manajemen Lingkungan (EMA, Environmental Management Accounting). Perspektif ekonomi ini menunjukan cara objektif untuk mengetahui dampak finansial terhadap kinerja lingkungan di industri secara fisik dan moneter ${ }^{8}$.

Dampak finansial dalam pengambilan keputusan yang berhubungan dengan isu-isu lingkungan, seringkali salah dalam perhitungannya akibat adanya biaya yang tidak terlihat (hidden cost) maupun overhead cost apabila menggunakan metode perhitungan akuntansi konvensional. Untuk dapat melihat secara lebih jelas lingkup biaya lingkungan, maka telah dikembangkan Environmental Management Accounting (EMA) sebagai perangkat untuk membantu para pelaku usaha dalam meningkatkan performa finansial sekaligus kinerja lingkungannya. Secara sistematis, EMA 
mengintegrasikan aspek lingkungan dari perusahaan ke dalam akuntasi manajemen dan proses pengambilan keputusan. Selanjutnya EMA membantu pelaku usaha untuk mengumpulkan, menganalisa dan menghubungkan antara aspek lingkungan dengan informasi moneter maupun fisik.

Dalam setiap proses produksi tentu memerlukan bahan baku sebagai input utamanya, energi sebagai sumber bahan bakar, serta air sebagai bahan penunjang. Dengan teknologi proses yang sesuai serta melibatkan tenaga kerja yang ahli dalam tiap tahapan atau sub-prosesnya maka pada akhirnya akan menghasilkan produk sesuai dengan yang direncanakan sebelumnya.
Melalui langkah-langkah produksi tersebut maka dapat digambar model alur bahan proses produksi, tahapan produksi hingga akhirnya menghasilkan produk. Pada model alur bahan tiap tahapan atau sub-proses produksi akan terlihat dengan jelas dan detail kebutuhan bahan baku, energi, peralatan yang diperlukan serta keterlibatan tenaga kerjanya. Mendasarkan pemahaman singkat tentang alur bahan tersebut maka yang dimaksud dengan Non Produk Output (NPO) adalah keseluruhan materi, energi dan air yang digunakan dalam proses produksi akan tetapi bahan tersebut tidak berakhir (termasuk) ke dalam produk akhir yang direncanakan ${ }^{9}$. Untuk lebih jelasnya pengertian NPO dapat dilihat pada Gambar 1.berikut:

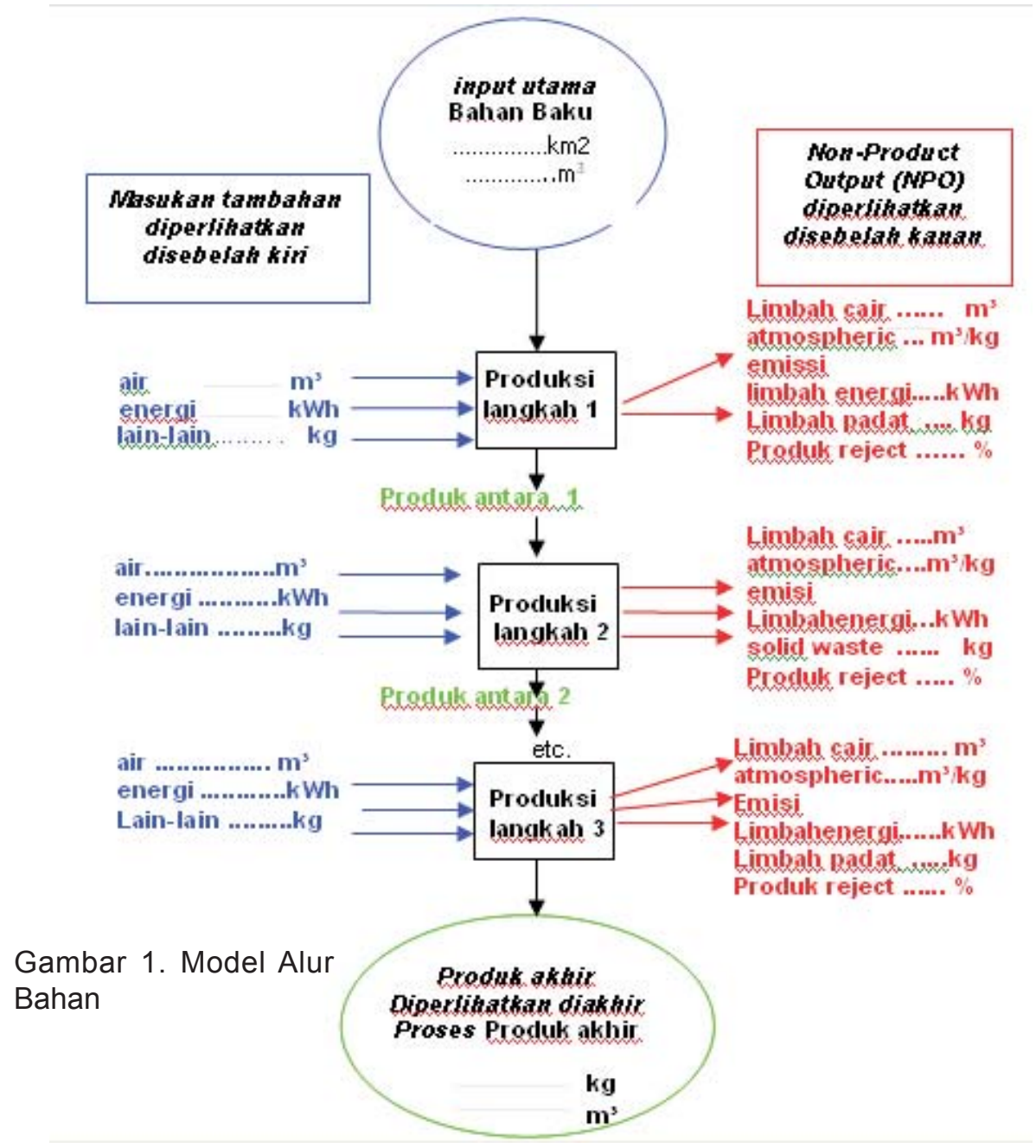


Pada Gambar 1 terlihat bahwa NPO berada disebelah kanan yang pada hakekatnya adalah limbah baik limbah cair, limbah padat, produk buangan atau produk gagal, serta emisi. Komponen-komponen atau unsur NPO tersebut mempunyai nilai atau yang disebut dengan biaya NPO. Biaya NPO terbentuk dari seluruh komponen yang membentuk NPO yaitu Biaya Input, Biaya Pemrosesan serta Biaya Pembuangan. Lebih lanjut skema perhitungan biaya NPO dapat dilihat seperti pada Gambar 2 berikut ini. d. Limbah cair (jumlah, tingkatan kontaminasi $=$ keseluruhan air tidak terkandung dalam produk final)

e. energi (tidak terkandung dalam produk final), contoh: batu bara, uap, listrik, oli, diesel, bensin, limbah panas)

f. emisi (termasuk kebisingan dan bau)

g. Kehilangan dalam penyimpanan

h. Kerugian pada saat penanganan dan transportasi (internal,eksternal)

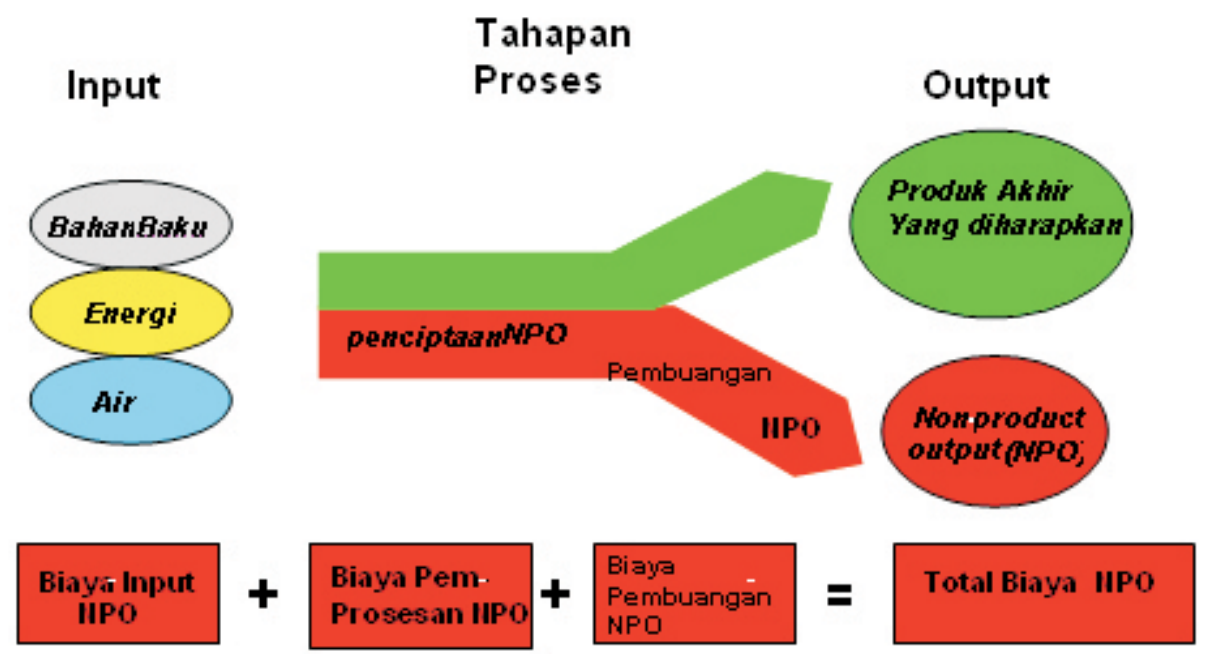

NPO = seluruh materi, energi dan air yang digunakan dalam proses produksi akan tetapi tidak berakhir (termasuk) ke dalam produk akhir

Gambar 2. Konsep dan Perhitungan NPO

Berdasarkan pada definisi dari NPO seperti terlihat pada Gambar 2, maka tipe dan bentuk-bentuk NPO atau biaya-biayanya yang dapat diidentifikasi adalah :

a. Bahan baku yang kurang berkualitas, artinya bahan baku yang tidak memenuhi kualitas (tidak sesuai spesifikasi)) yang sudah ditetapkan oleh industri.

b. Barang yang ditolak, diluar spesifikasi produk (semua tipe), dan biaya pemrosesan kembali

c. Limbah (padat, cair, beracun, tidak beracun) i. Pengemasan Material (kecuali parfum atau produk serupa)

j. Reklamasi pelanggan dan trade returns

k. Kerugian karena kurangnya perawatan

I. Kerugian atau permasalahan kesehatan dan lingkungan

m. Kapasitas yang digunakan dalam pemprosesan kembali (reprocessing) (peluang biaya)

n. machine downtimes 
Internalisasi biaya lingkungan skala perusahaan adalah memasukkan item-item biaya yang sebelumnya bukan manjadi bagian dari biaya lingkungan menjadi biaya lingkungan seperti biaya pengelolaan limbah, pelatihan di bidang lingkungan, sertifikasi dan labeling lingkungan (ISO 14000) yang merupakan biaya-tidak langsung, biaya lingkungan langsung seperti biaya energi yang diperlukan untuk menghasilkan produk, biaya tenaga kerja untuk memproses produk, biaya bahan dan material untuk memproduksi suatu produk. Masih dalam tataran perusahaan, biaya lingkungan secara akuntansi konvensional masuk dalam kategori overhead cost (biasanya berupa biaya limbah dan atau pembakaran limbah) sehingga beban lingkungan dibebankan secara makro, sedangkan upaya internalisasi lingkungan (skala perusahaan) adalah upaya secara lebih terinci beban atau biaya lingkungan dari aspek apa saja yang secara nyata memang menghasilkan biaya lingkungan ${ }^{9}$. Dengan demikian melalui internalisasi biaya lingkungan akan dapat diketahui berapa biaya lingkungan yang nyata pada masing-masing devisi serta tahapan prosesnya sehingga sumber-sumber pencipta beban lingkungan dapat dilihat secara lebih terperinci. Pemahaman secara konvensional tentang biaya lingkungan adalah keseluruhan biaya perlindungan lingkungan dalam arti biaya yang diperlukan untuk pemulihan dampak lingkungan. Sedangkan pemahaman biaya lingkungan yang mengacu pada aliran bahan/material dan energi adalah biaya-biaya yang terkait dengan aliran bahan dan energi yang berdampak terhadap lingkungan.

Dengan mengacu pada pemahaman aliran bahan dan energi, maka biaya lingkungan akan terkait dengan :

- $\quad$ Biaya material sebagai input untuk manjadi produk/output, yaitu biaya belanja sumber alam, energi, air dan material lainnya serta pengemasan produk.
- Biaya material dari non produk output, yaitu biaya energi pada tahapan proses, air dan material lain yang menjadi Non Produk Output

- Pengendalian biaya limbah dan emisi, meliputi penanganan dan perlakuan terhadap buangan limbah dan emisi, serta biaya kompensasi akibat kerusakan lingkungan.

- $\quad$ Pencegahan dan biaya managemen lingkungan, meliputi seluruh biaya aktifitas managemen lingkungan, perencanaan lingkungan dan komunikasi lingkungan,

- Biaya Penelitian dan Pengembangan, mencakup penelitian yang terkait isuisu lingkungan.

- $\quad$ Biaya-biaya yang terukur, antara lain citra perusahaan, peraturan-peraturan dimasa depan, relasi pemegang saham, potensi kecenderungan perusahaan dimasa mendatang.

Biaya yang umum dibebankan pada lingkungan adalah: Biaya pengolahan limbah, dan atau biaya incinerator (pembakaran limbah padat). Sedangkan biaya yang tersembunyi adalah biaya ; biaya energi untuk material limbah, biaya pengadaan bahan yang akhirnya menjadi limbah, tambahan biaya akibat penampungan limbah, biaya proses material limbah, biaya administrasi untuk proses limbah dan material limbah, biaya penanggulangan kerusakan (abrasi) akibat material limbah, biaya tenaga kerja untuk proses pengolahan limbah dan material limbah.

\section{PELUANG PENERAPAN PADA INDUSTRI PERIKANAN}

Dengan pendekatan NPO seperti yang sudah diuraikan sebelumnya maka secara jelas dapat membantu untuk mengidentifikasi dan menganalisa biaya lingkungan yang tersembunyi (hidden cost), misalnya biaya minimisasi limbah yang hanya memasukkan biaya insenerasi dan pembuangan limbah, 
namun juga memasukkan komponen biaya material, komponen peralatan , serta tenaga kerja. Artinya secara lebih rinci jumlah nilai atau biaya yang dibebankan pada masingmasing komponen akan dapat dihitung dengan pendekatan tiap-tiap tahapan proses sesuai dengan diagram alur bahan. Biaya-biaya lingkungan yang dapat diketahui secara lebih rinci antara lain adalah : biaya energi dari material yang jadi limbah, biaya pembelian material yang jadi limbah, biaya penyimpanan limbah, biaya proses limbah, biaya administrasi proses penanganan limbah, biaya tenaga kerja pengolahan limbah, biaya kerusakan mesin akibat limbah material, kontribusi biaya tenaga kerja produk terbuang atau reject , biaya alat (depresiasi) proses produk terbuang atau reject. Dengan melihat hasil perhitungan biaya NPO maka dapat diketahui titik-titik atau bagian proses mana saja yang nilai biaya NPO nya tinggi sehingga informasi tersebut dapat membantu pada proses pengambilan keputusan. Keputusan yang menguntungkan harus didasarkan pada berbagai informasi penting seperti yang diperlihatkan pada pendekatan NPO tersebut.

Berdasarkan pada informasi besarnya pemborosan pada tahapan proses tertentu pengambil keputusan akan mencari penyebab secara lebih akurat, sehingga upaya perbaikan akan benarbenar dapat dipertanggungjawabkan. Dengan demikian dengan pendekatan biaya NPO akan dapat membuka kembali biaya produk dan proses yang lebih spesifik yang seringkali tersembunyi dalam bagian overhead cost. Pendekatan perhitungan NPO juga akan memberikan solusi yang saling menguntungkan secara ekonomis dan lingkungan. Dalam arti bahwa melalui upaya perbaikan dapat menghasilkan penghematan atau efisiensi, disisi lain upaya perbaikan tersebut dapat menurunkan dampak lingkungan dari produk maupun pada tahap proses produksi. Dengan demikian kegiatan usaha diharapkan akan mempunyai performa lebih baik baik pada sisi ekonomi maupun sisi lingkungan.
Secara umum industri-industri besar yang ada di Muncar bergerak pada bidang pengalengan ikan dan tepung ikan, dimana tepung ikan dihasilkan sebagai produk olahan ke-3 yang bahan-bahannya bersumber dari produk samping (non limbah) proses pengalengan ikan. Sedangkan ikan yang dipergunakan adalah ikan Lemuru (Sardinella Lemuru), yang merupakan komoditas hasil laut utama dan khas di Muncar. Industri perikanan dalam prosesnya memerlukan air bersih yang cukup banyak, sehingga limbah cair yang dihasilkan juga banyak.

Berdasarkan pada proses produksi pengalengan ikan sardinella lemuru, beberapa bentuk non-efisiensi atau pemborosan yang ditemui pada industri pengalengan dan penepungan ikan di Muncar adalah sebagai berikut:

1. Proses sortasi bahan baku ikan pada tahap awal yang tidak efisien, terutama bahan baku yang menggunakan ikan beku, dimana proses thawing (pelelehan) banyak memakan waktu dan kualitas ikan yang masuk dalam proses tidak terseleksi dengan baik, sehingga proses sortir (pilihan) masih terjadi pada tahapan proses lebih lanjut.

2. Pemborosan air di semua tahapan proses produksi, karena air yang digunakan adalah air bersih, bukan air hasil daur ulang.

3. Pemborosan bahan baku pada proses pengisian ke dalam kaleng, baik itu daging ikan atau saus bumbu.

Oleh karena itu peluang penerapan yang dapat dijadikan bahan upaya perbaikan untuk meningkatkan efisiensi dan kinerja lingkungan di kawasan industri perikanan Muncar adalah :

1. Potensi penghematan penggunaan air pada saat pencucian ikan dan penyiangan ikan di proses pembuatan sarden 
2. Potensi penghematan pada proses penyiangan ikan, karena ikan banyak yang jatuh (tidak terpilih), pada hal masih memenuhi standar kriteria untuk dipilih.

3. Penghematan pada pengelolaan Gudang Penyimpanan ikan sebelum digiling menjadi tepung. Menerapkan GHK untuk meningkatkan efisiensi dan optimalisasi bahan baku.

Dengan mengembangkan analisis NPO (non product output) berdasarkan perhitungan nilai rupiah yang hilang pada setiap tahap yang tidak efisien, serta membuat tahap-tahap perbaikan secara partisipatif, yang dapat langsung mereka aplikasikan dalam rangka meminimalisasi proses tahapan produksi di dalam industri mereka yang tidak efektif dan efisien. Untuk itu maka peluang untuk meningkatkan efisiensi dan kinerja lingkungannya adalah sebagai berikut :

\section{Efisiensi Bahan Baku Ikan, melalui sortasi ulang yang lebih efektif.}

Tindakan yang dilakukan melalui cara mengatur pasokan atau suplai bahan baku ikan yang masuk ke dalam meja sortasi/ penyiangan tidak sampai terlalu penuh, dan sortasi ulang ikan yang jatuh tercecer ke lantai. Hal ini mengurangi jumlah ikan afkir, terutama ikan kualitas baik yang terpaksa terbuang karena jatuh tercecer. Alasan utama dilakukan tindakan efisiensi ini karena banyak bahan baku ikan yang masih segar dan tidak rusak menjadi afkir karena jatuh tercecer di lantai yang terpaksa langsung disingkirkan melalui proses penggelontoran (flushing) untuk menjaga ruang proses produksi tetap higienis. Pendekatan teknologi yang dapat dilakukan adalah dengan cara membuat penahan atau pembatas pada meja sortasi atau belt berjalan, serta mengatur waktu suplai ikan yang masuk ke dalam meja sortasi atau penyiangan.

\section{Efisiensi Penggunaan Air Bersih Yang Berlebihan Pada Tahapan Proses Penyiangan dan Pencucian Ikan.}

Tindakan yang dilakukan adalah dengan cara membuat sprayer tekanan tinggi dengan memperkecil diameter pipa kran air pada bagian penyiangan dan pencucian, dengan tujuan mempercepat proses pembersihan serta mengurangi jumlah total debit air yang keluar. Selain itu dapat pula dilakukan melalui memutar ulang air bekas pencucian untuk penggelontoran (flushing) limbah hasil penyiangan berupa kepala, ekor, sisik, isi perut dan ikan yang telah rusak. Alasan utama dilakukan tindakan ini karena selama ini air yang digunakan pada proses penggelontoran limbah penyiangan adalah air bersih. Pendekatan teknologi yang dilakukan adalah dengan membuat pipa air tambahan dari rotary washer untuk mengalirkan air bekas cucian kembali ke proses penyiangan untuk penggelontoran limbah hasil penyiangan.

\section{Efisiensi ceceran pada proses pengisian kaleng.}

Tindakan yang dilakukan adalah memperkecil diameter lubang pada pipa saus sehingga debit saus yang keluar tidak berlebihan, selain itu mengatur kontinuitas kaleng siap isi yang bergerak di atas belt. Alasan utama dilakukan tindakan efisiensi ini karena selama ini pengisian saus ke dalam kaleng menggunakan tekanan pada jarak yang tidak terlalu dekat di atas kaleng sehingga untuk mencapai tujuan saus bisa terisi merata ke dalam kaleng sering berkendala karena timbul kantung udara di dalam kaleng, sehingga saus bertekanan tertekan balik dan tumpah keluar. Selain itu sering terjadi bahwa kaleng jadi terisi terlalu penuh, yang terpaksa harus dikurangi dengan dibuang pada tahap head space , dimana pada tahap ini ruang pada bagian atas kaleng harus kosong $\pm 10 \%$ agar pada tahap sterilisasi ada ruang hampa di dalam kaleng. 


\section{PENUTUP}

Walaupun perkembangan teknologi lingkungan sudah mengarah pada upaya pencegahan limbah sejak dari hulunya, pada kenyataannya penerapan teknologi end-ofpipe tetap masih dominan. Hal tersebut terjadi disamping karena tidak mudahnya merubah proses industri yang sudah establis, juga perusahaan-perusahaan pembuat teknologi end of pipe sudah cukup lama berperan di pasar sehingga akan terus berusaha bertahan. Berdasarkan proses produksi industri perikanan yang ada di Kecamatan Muncar, maka peluang diterapkannya prinsip produksi bersih sangatlah besar, mengingat penggunaan bahan baku utama berupa ikan, dan bahan baku penunjangnya berupa air bersih masih banyak mengalami pemborosan. Peluang penerapan produksi bersih terutama pada tahapan penggunaan air bersih yang berlebihan pada proses penyiangan dan pencucian Ikan, tahapan penggunaan bahan baku utama ikan dengan cara sortasi ulang yang lebih efektif, serta efisiensi ceceran pada proses pengisian kaleng.

\section{DAFTAR PUSTAKA}

1. Fleig, A., ECO-Industrial Parks. A Strategy towards industrial ecology in Developing and Newly Industrialized Countries,2000, GTZ.

2. Potter, C. Limbah Cair Berbagai Industri di Indonesia, Sumber, Pengendalian dan Baku Mutu EMDIBAPEDAL, Project of The Ministry of State for Environment, Republic of Indonesia and Dalhousie University, 1994 Canada, Jakarta.

3. Djajadiningrat, S.T, Famiola, M., Kawasan Industri Berwawasan Lingkungan, 2004, Rekayasa Sains, Bandung.

4. ,UNEP, United Nations

Environmental Program, www.unep. org
5. -----------, Undan-Undang No 32 Tahun 2009 Tentang Perlindungan dan Pengelolaan Lingkungan

6. Van Berkel, R., 2001, Cleaner Production for Achieving Ecoefficiency in Australian Industry, Curtin University of Technology, Pert http://cleanerproduction.curtin.edu. au.

7. - ------ International Federation of Accountants IFAC, 1998: Environmental Management in Organizations. The Role of Management Accounting. Study 6. New York,

8. -----------,Study Of Management Accounting 1980, The Centre for Sustainability Management (CSM), University of Lueneburg, Germany'

9. - -------, Environmental Management Accounting 2003, Society for Environmental Protection (ASEP) Bangkok, Thailand.

10. Stefan Schaltegger, Prof. Dr.; Concept of eco-efficiency 1980 . University of Lueneburg, Germany 